Rajshahi University journal of life \& earth and agricultural sciences

ISSN 2309-0960 Vol. 40: 15-22, 2012

\title{
A comparative study on violent and aggressive attitudes and activism among students and non-students
}

\author{
Shawkat Ara, Md. Abul Kashem Mir, Syeda Shahria Samad \& Rasel Ahmed* \\ Department of Psychology, University of Rajshahi, Rajshahi 6205, Bangladesh. \\ Corresponding author: ahmedraselpsy@yahoo.com
}

\begin{abstract}
The purpose of this study was to investigate the violent and aggressive attitudes for student activists, non-student activists and student non-activists of different educational institutions within the framework of socio-cultural background. The study has been developed under the theoretical interpretation of biological theory of aggression and violence, and social learning theory of aggression and violence. It uses a multidimensional co relational approach with a criterion group design. The study was conducted into two phases. In the first phase criterion groups of student activists, non student activists and student non activists were selected on the basis of an activism criteria questionnaire. To achieve the goal 360 respondents was equally taken from student activists, non-student activists and student non-activists. Each sample group was sub-divided into upper middle and lower middle SES background. The violent and aggressive attitudes composed of five dimensions- such as political violence, social violence, institutional violence, administrative violence and sex violence in the violence - nonviolence continuum. The main objective of the present investigation was to make a comparative study of the pattern of the attitudes of student activists, non-student activists and student non-activists. In this Study it was hypothesized that student activists would score higher on the attitudinal variables of violent and aggressive attitudes as compared to non-student activists and student non-activists respectively. The data were analyzed to obtain Mean, SD \& t-test to test hypothesis. The result revealed that student activists were found to possess higher score on the attitudinal variable of violent and aggressive attitudes as compared to non-student activists and student non-activists respectively.
\end{abstract}

Keywords: Violence, aggression, attitudes, activists, socio-economic status.

\section{Introduction}

The study of aggressive and violent attitudes has become a significant area of research in several social science disciplines in Western (Berkowitz, 1962; Bandura, 1973; Baron, 1977; Miller \& Challas, 1981; Allen \& Santrock, 1993) as well as in Eastern countries like India (Altbach, 1968; Bhatt, 1972; Sinha, 1972) and Bangladesh (Ara, 1983, 2007; Begum \& Parveen, 1984; Begum \& Rahman, 1986; Hussain, 1987; Begum \& Begum, 1993; Kashem, 2008). Aggression and violence are a constant pre-occupation of our societies all over the world. An over view of the statistics of aggressive and violent acts in the West as well as in the East including Bangladesh indicate that the figures are rising very high. Activism is universally attached to the search for self-identity. It emerges out of conflicts existing in societal framework due to ideological differences.

Aggression has been defined by Dollard et al. (1939) as any sequence of behaviour, the goal response of which is the injury of the person toward whom it is 
directed. Similarly, Berkowitz (1981) defined aggression as a behaviour directed toward the injury of some target. Baron (1977) conceived aggression as any form of behaviour directed toward the goal of harming or injuring another living being who is motivated to avoid such treatment. This definition is more of interpersonal or social nature and emphasized upon three aspects viz., (1) aggression is a goal directed behaviour, (2) intention of injuring another persons and (3) it involves a victim motivated to avoid such treatment by an aggressor.

Violence on the other hand, is usually differentiated from other forms of aggression in terms of the severity of the injury. It is characterized by a deliberate attempt to do serious physical harm to the victim (Berkowitz, 1962). In other words, violence is defined as an unlawful exercise of physical forces (Buss, 1971). Kempe (1986) maintains that violence is physically striking an individual and causing injury. Thus, while aggression is a more general term implying intent of inflicting injury to others. Violence refers to the severe overt application of force resulting in the injury or destruction of persons or property or reputation as well as overt severe threat of injury that may result in trauma. In other words, violence conveys the heated, the achievement expression of aggressions' feelings to victims.

The distinctive feature of activists is the unexpected emergence of a vocal minority of politically and socially active individuals very much related to aggression and violent acts. An activist may be defined as an individual who (a) acts together with others in a group, (b) is concerned with some ethical, social, ideological or political issue and (c) holds conservative or radical views; the sources of student activism and non student activism protest are complex and inter-related. Protest-prone individual might be student activists and non student activists (Aiken et al., 1966; Paulus, 1967).

Heist and Somers (1965) conducted a survey on the student activists in Berkely's Free Speech Movements at the University of California. There were three comparison groups. They were (1) arrested members $(\mathrm{N}=130)$ from free speech Movements, (2) Berkeley seniors ( $\mathrm{N}=92)$ who participated in the demonstrations, and (3) those typical college students $(\mathrm{N}=1385)$ who are studying in colleges for four years. The result showed that few college students in general can match the positive development of those personality characteristics that distinguished student activists from their college contemporaries. Peterson (1966) also conducted a survey of the state of activism as viewed by deans of students and equivalent officers and found that only 9 percent of any student body was reported as involved in protest movements. Austin et al. (1967) collected data from a random sample of entering college freshmen in the beginning of 1966. It was found from the analysis of this data that $15 \%$ of the women and 16 percent of the men had participated in many sort of demonstration either these were activistic or not.

Ara (1983) did an extensive pioneering study to find out the similarities and differences of socio-political attitudes of activists and non-activist in India and Bangladesh in relation to certain ideological preferences like right and left within 
the framework of socio-cultural background. The result showed that Bangladeshi activists both right and left exhibited more activism as compared to Indian rightleft activists. But, as a whole leftist in both countries were more activistic. Another study, Ara (1990) explored the phenomenon of student political activism in Bangladesh as related to sex and socioeconomic status (SES) differences. It was found that males scored significantly higher on political activism as compared to the females. So in Bangladesh politics, gender variation and status differentiation had been playing a major role. In her another study Ara (1998) investigate the factors of political behaviour relating to student unrest of different ideological group in the Universities of Bangladesh. Haque (2002) attempted at investigating political behaviour relating to intergeneration gap in Bangladesh. Kashem (2008) did an extensive pioneering study investigating the similarities and differences of violent-aggressive attitudes for student activists, non student activists and student non activists of different educational institution of northern part of Bangladesh within the framework of socio-cultural background in Bangladesh. The result showed that student activists exhibited more activism on the attitudinal variable of violent and aggressive attitudes as compared to non-student activists and student non-activists respectively.

Hypothesis: It was thus hypothesized that student activists would score higher on the attitudinal variables of violent and aggressive attitudes as compared to nonstudent activists and student non-activists respectively.

\section{Materials and methods}

Sample: The sample of the study was constituted 360 respondents equally divided into student activists, non-student activists and student non-activists on each group separately $(\mathrm{N}=120)$. Each sample was sub-divided into upper middle and lower middle SES background on each composed of 60 respondents.

Instrument: Bengali version of Violent and Aggressive Attitude Scale was used for data collection. The scale contained 26 items having 5 dimensions. To find out the validity of the scale, correlation of each dimension with the total scores of the study were computed which ranged from 0.39 to 0.57 . The split-half reliability of the present form scale was 0.71 .

Procedure: Bengali version of Violent and Aggressive Attitude Scale was administered on 360 Ss individually. They were asked to answer 45 items. Ss were properly instructed and the data were collected properly.

Method of analysis: The collected data were properly coded. Scoring was made for each respondent separately. Statistical analysis of Mean, SD, 't' tests and ' $r$ ' were computed.

\section{Results}

The results of the present study were analyzed by computing Mean, SD and t test. In this analyses t-test were computed showing the mean differences between Student Activists-Non Student Activists, Student Activists-Student Non Activists, and Non Student Activists-Student Non Activists. 
Table 1. Showing mean differences between student activists and non student activists on each variable separately $(\mathrm{N}=120)$.

\begin{tabular}{|c|c|c|c|c|c|c|c|}
\hline & & $\begin{array}{c}\text { Violent - } \\
\text { aggressive } \\
\text { attitudes }\end{array}$ & $\begin{array}{c}\text { Political } \\
\text { violence }\end{array}$ & $\begin{array}{c}\text { Social } \\
\text { violence }\end{array}$ & $\begin{array}{c}\text { Institutional } \\
\text { violence }\end{array}$ & $\begin{array}{c}\text { Administrative } \\
\text { violence }\end{array}$ & $\begin{array}{c}\text { Sex } \\
\text { violence }\end{array}$ \\
\hline \multirow{2}{*}{ SA } & Mean & 163.25 & 35.07 & 34.13 & 32.59 & 32.35 & 29.11 \\
\cline { 2 - 8 } NSA & 21.25 & 9.62 & 9.52 & 9.78 & 8.82 & 8.31 \\
\hline & Mean & 145.75 & 30.09 & 29.26 & 25.45 & 29.13 & 31.82 \\
\hline & SD & 19.29 & 8.95 & 8.81 & 8.89 & 7.67 & 7.45 \\
\hline
\end{tabular}

$* *=\mathrm{p}<0.01$ SA $=$ Student activists $\quad$ NSA $=$ Non student activists

Table 1 shows that student activists $(M=163.25)$ were found significantly more violent and aggressive $(\mathrm{t}=6.66, \mathrm{df}=238, \mathrm{p}<0.01)$ as compared to non student activists $(M=145.75)$. Student activists $(M=35.07)$ expressed significantly more violent and aggressive attitudes on the dimension of 'political violence' $(\mathrm{t}=4.15$, $\mathrm{df}=238, \mathrm{p}<0.01)$ as compared to non student activists $(\mathrm{M}=30.09)$. Again the result indicated that student activists $(\mathrm{M}=34.13)$ as significantly more violent and aggressive on the dimension of 'social violence' ( $\mathrm{t}=4.11$, $\mathrm{df}=238, \mathrm{p}<0.01$ ) as compare to non student activists $(M=29.26)$. It was also found that Student Activists $(\mathrm{M}=32.59)$ significantly expressed more violent and aggressive attitudes on the dimension of 'institutional violence' ( $\mathrm{t}=5.92, \mathrm{~d}=238, \mathrm{p}<0.01$ ) as compared to non student activists $(M=25.45)$. Again the result showed that student activists $(\mathrm{M}=32.35)$ expressed significantly more violent and aggressive attitudes on the dimension of 'administrative violence' $(\mathrm{t}=3.02, \mathrm{df}=238, \mathrm{p}<$ $0.01)$ as compared to non student activists $(M=29.13)$. The result also showed that non student activists $(M=31.82)$ expressed significantly more violent and aggressive attitudes on the dimension of 'sex violence' $(\mathrm{t}=2.66, \mathrm{df}=238, \mathrm{p}<$ $0.01)$ as compared to student activists $(M=29.11)$.

Table 2. Showing mean differences between student activists and student non activists on each variable separately $(\mathrm{N}=120)$.

\begin{tabular}{|c|c|c|c|c|c|c|c|}
\hline & & $\begin{array}{c}\text { Violent - } \\
\text { aggressive } \\
\text { attitudes }\end{array}$ & $\begin{array}{c}\text { Political } \\
\text { violence }\end{array}$ & $\begin{array}{c}\text { Social } \\
\text { violence }\end{array}$ & $\begin{array}{c}\text { Institutional } \\
\text { violence }\end{array}$ & $\begin{array}{c}\text { Administrative } \\
\text { violence }\end{array}$ & $\begin{array}{c}\text { Sex } \\
\text { violence }\end{array}$ \\
\hline \multirow{2}{*}{ SA } & Mean & 163.25 & 35.07 & 34.13 & 32.59 & 32.35 & 29.11 \\
\cline { 2 - 8 } NSA & SD & 21.25 & 9.62 & 9.52 & 9.78 & 8.82 & 8.31 \\
\cline { 2 - 8 } & Mean & 127.50 & 25.05 & 24.40 & 29.21 & 25.19 & 23.65 \\
\hline & t - value & 18.64 & 8.86 & 8.95 & 8.69 & 8.55 & 8.13 \\
\hline
\end{tabular}

** $=\mathrm{p}<0.01 \quad$ SA $=$ Student Activists $\quad$ SNA $=$ Student Non Activists

Table 2 shows that student activists $(M=163.25)$ expressed significantly more violent and aggressive attitudes $(\mathrm{t}=13.82, \mathrm{df}=238, \mathrm{p}<0.01)$ as compared to student non activists $(\mathrm{M}=127.50)$. The result also found that student activists $(\mathrm{M}$ $=35.07$ ) expressed significantly more violent and aggressive attitudes on the dimension of 'political violence' $(\mathrm{t}=8.39$, $\mathrm{df}=238, \mathrm{p}<0.01)$ as compared to student non activists $(\mathrm{M}=25.05)$. Again the result indicated that student activists 
$(\mathrm{M}=34.13)$ were significantly more violent and aggressive on the dimension of 'social violence' ( $\mathrm{t}=8.16, \mathrm{df}=238, \mathrm{p}<0.01$ ) as compared to student non activists $(M=24.40)$. It was also found that student activists $(M=32.59)$ were significantly more violent and aggressive attitudes on the dimension of 'institutional violence' $(\mathrm{t}=2.83, \mathrm{~d}=238, \mathrm{p}<0.01)$ as compared to student non activists $(\mathrm{M}=29.21)$. Again the result showed that student activists $(M=32.35)$ expressed significantly more violent and aggressive attitudes on the dimension of 'administrative violence' $(\mathrm{t}=6.39$, $\mathrm{df}=238, \mathrm{p}<0.01)$ as compared to student non activists $(\mathrm{M}=$ 25.19). The result also showed that student activists $(M=29.11)$ expressed significantly more violent and aggressive attitudes on the dimension of 'sex violence' $(\mathrm{t}=5.15, \mathrm{df}=238, \mathrm{p}<0.01)$ as compared to student non activists $(\mathrm{M}=$ 23.65).

Table 3. Showing mean differences between non student activists and student non activists on each variable separately $(\mathrm{N}=120)$.

\begin{tabular}{|c|c|c|c|c|c|c|c|}
\hline & & $\begin{array}{c}\text { Violent - } \\
\text { aggressive } \\
\text { attitudes }\end{array}$ & $\begin{array}{c}\text { Political } \\
\text { violence }\end{array}$ & $\begin{array}{c}\text { Social } \\
\text { violence }\end{array}$ & $\begin{array}{c}\text { Institutional } \\
\text { violence }\end{array}$ & $\begin{array}{c}\text { Administrative } \\
\text { violence }\end{array}$ & $\begin{array}{c}\text { Sex } \\
\text { violence }\end{array}$ \\
\hline \multirow{2}{*}{ SA } & Mean & 145.75 & 30.09 & 29.26 & 25.45 & 29.13 & 31.82 \\
\cline { 2 - 9 } NSA & SD & 19.29 & 8.95 & 8.81 & 8.89 & 7.67 & 7.45 \\
\cline { 2 - 9 } & Mean & 127.50 & 25.05 & 24.40 & 29.21 & 25.19 & 23.65 \\
\hline & t - value & 18.64 & 8.86 & 8.95 & 8.69 & 8.55 & 8.13 \\
\hline
\end{tabular}

$* *=\mathrm{p}<0.01 \quad \mathrm{NSA}=$ Non Student Activists, SNA $=$ Student Non-Activists

Table 3 shows that non student activists $(M=145.75)$ expressed significantly more violent and aggressive attitudes $(\mathrm{t}=7.45 \mathrm{df}=238, \mathrm{p}<0.01)$ as compared to student non activists $(\mathrm{M}=127.50)$. The result also showed that non student activists $(M=30.09)$ expressed significantly more violent and aggressive attitudes on the dimension of 'political violence' ( $\mathrm{t}=4.38$, $\mathrm{df}=238, \mathrm{p}<0.01)$ as compared to student non activists $(\mathrm{M}=25.05)$. Again the result indicated that non student activists $(M=29.26)$ were significantly more violent and aggressive on the dimension of 'social violence' $(\mathrm{t}=4.24$, $\mathrm{df}=238, \mathrm{p}<0.01)$ as compared to student non activists $(\mathrm{M}=24.40)$. It was also found that non student activists $(\mathrm{M}=$ 25.45) were significantly more violent and aggressive on the dimension of 'institutional violence' $(\mathrm{t}=3.31, \mathrm{~d}=238, \mathrm{p}<0.01)$ as compared to student non activists $(M=29.21)$. Again the result showed that non student activists $(M=$ 29.13) expressed significantly more violent and aggressive attitudes on the dimension of 'administrative violence' ( $\mathrm{t}=3.76 \mathrm{df}=238, \mathrm{p}<0.01$ ) as compared to student non activists $(\mathrm{M}=25.19)$. The result also showed that non student activists $(M=31.82)$ expressed significantly more violent and aggressive attitudes on the dimension of 'sex violence' ( $\mathrm{t}=8.12$, $\mathrm{df}=238, \mathrm{p}<0.01$ ) as compared to student non activists $(\mathrm{M}=23.65)$.

\section{Discussion}

In the present study, the student activists, non student activists and student non activists were included as a sample of the study. The theoretical interpretation and review of the literature suggest that any attempt at understanding violent and 
aggressive attitudes in the political and cultural context of Bangladesh in which this study has been carried out to understand the process of political activism by the students or non-student activists. After independence of Bangladesh in 1971 the democratic process of politics though started but different times it has been interacted and disturbed by the authoritarian and half democratic process through various types of political cultures (Almond \& Verba, 1963; Sinha, 1972; Ara, 1983). In Bangladesh general mass of people always participated and expressed activistic role for achieving their rights for Bengali Language, independence and socio-economic and political democracy. In the present study it is also proved that not only the students played activistic role but also the non student activists who came from differential political orientations and belong to different sector of service, business, agriculture and other backgrounds participated in the activistic role. It means that a political culture of the individual is an integral aspect of more general culture mixed with religious dogma and socio-economic awareness.

In conclusion it can be said that Bangladesh is predominantly a cultural society along with political society. The social values and religious dogmas though are more important to the masses than political values, but it cannot be neglected. In fact, political culture is highly concerned with rights and privileges between different classes of people. In the absence of democratization of power, political culture can not flourish. In Bangladesh there is clearly a vacuum of political teaching in absence of democratic system of government. In a word, it can be said that Bengali history and tradition, Bengali life and customs and Islamic religion have tremendous impact on the development of political culture in Bangladesh. Moreover, culture is a dynamic process and political culture of Bangladesh, is at a formative stage, contingent upon resistant to social change and development of the country.

The analyses on data on violent-aggressive attitudes scale showed that student activists Ss differed significantly from the non student activists Ss and student non activists Ss on violent-aggressive attitudes. Student activists were found to possess more violent and aggressive attitudes on the four dimensions such as political, social, institutional, and administrative violence as compared to non student activists and student non activists. Student non activists, on the other hand, were found less violent-aggressive attitudes towards the four dimensions of political, social, institutional, administrative violence in comparison to student activists, non student activists. Moreover, non student activists were found to posses less violent and aggressive attitudes towards the five dimensions of political, social, institutional, administrative and sex violence in comparison to student activists but possessed more violent and aggressive attitudes towards these five dimensions in comparison to student non activists. Thus non student activists were found to belong in the middle position in comparison to student activists and student non activists.

The characteristics difference between student activists and student non activists fall within the theoretical explanation given by different Western and Eastern investigators (Keniston, 1967; Altbach, 1968; Sinha, 1972; Ara, 1988, Begum \& Begum, 1993; Kashem, 2008). They explained that the student activists as though 
they were a totally undifferentiated group, it may be more reasonable to consider the activist response as one of a variety of ways of coping with a rapidly changing political, social and economic environment. The development of a typology of these various responses would lead much clarity to the entire matter of student activism.

The student non activists though they participate in all activities associated with the student activists, but they did not show extreme activistic task. They thought that they have admitted in the college or University for building their career. After some years they have to achieve the degree for getting job. Moreover, though they have political attitudes in cognitive and feeling component, but they do not show it in action tendencies. Thus, they expressed less violent and aggressive attitudes.

On the contrary, non student activists are the general public of the country. These individuals though they involve in some kind of activistic role like hartal, strike, etc. but they do not play unusual extreme activistic role. Besides the non student activists are also have to perform so many duties in their job, business or agriculture. They have to lead their family life also. But the activist work performed by the students has become a normal routine work in present educational system in Bangladesh. Hence in the present study student activists were found to express more violent and aggressive attitudes as compared to non student activists and student non activists. Thus, the hypotheses student activists would score higher on attitudinal variable of violent and aggressive attitudes as compared to non-student activists and student non activists respectively is confirmed.

In the present situation the administrator of Bangladesh has taken drastic attempt to discover unruly functioning of the activists and also has been trying to maintain discipline in every sector of the society. The study is concerning with the investigation of several factors that might have both predisposing and precipitating effects on activism of student as well as non students. The positive side of this investigation gives direction to the facts that student as well as non student activists are very must alert about their rights and demands. This violent and aggressive act directs these individuals in the process of political socialization for democratic process which can not be ignored in any way.

\section{References}

Aiken. M., Demerath. N. J. \& Marwell. G. 1966. Conscience and confrontation some preliminary findings on summer civil rights volunteers. University of Wisconsin.

Allen, L. \& Santrock, J. 1993. Psychology : the ontexts of behavior. Brown \& Benchmark Press, Madison.

Almond, G. A. \& Verba, S. 1963. The civic culture. Princeton University Press, Princeton.

Altbach, P.G. 1968. Student politics and higher education in India. In: Altbach, P.G. (ed): Turmoil and transition: higher education and student politics in India. Lalvani Publishing House, Bombay: 52-65.

Ara, S. 1983. A comparative study of socio-political attitudes of activities of India and Bangladesh. Ph.D. thesis. Department of Psychology, University of Allahabad.

Ara, S. 1988. Ideology and student Activism. University of Rajshahi.

Ara, S. 1990. A psychological study of student activism in Bangladesh. The Pakistan Journal of Psychological Research, 5(1-2): 33-41. 
Ara, S. 1998. Factors related to student unrest in the universities of Bangladesh. Final Report. University Grants Commission, Bangladesh.

Ara, S. 2007. Violence and aggression: a comparative psychological study between political and nonpolitical students in different educational institutions of Bangladesh. Final Report. University Grants commission, Bangladesh.

Austin, A.W., Panos, R.J. \& Creager, J.A. 1967. National norms for entering college freshman.. American Council of Education, Washington.

Bandura, A. 1973. Aggression: social learning analysis. Prentice-Hall, Englewood Cliffs.

Baron, R.A. 1977. Human aggression. Plenum, New York.

Begum, F. \& Begum, H.A. 1993. Explaining aggression and violence. a probe into social psychological factors. Socio Vision, Dhaka.

Begum, H.A. \& Parveen, E. 1984. Development of bengali version of Cassel's test of social insight, Dhaka University Journal of Psychology, 14:31-43.

Begum, H.A. \& Rahman, N. 1986. Violence against women: a study of some personality characteristics of aggressors. Paper Presented in Bangladesh Psychological Conference, University of Dhaka: 1-9.

Berkowitz, L. 1962. Aggression: A social psychological analysis. McGraw-Hill, New York.

Berkowitz, L. 1981. The concept of aggression. In: Brian, P.E. \& Benton, D. (eds): Multidisciplinary approaches to aggression research. Elsevier/North Holland, New York: 3-15.

Bhatt, P.N. 1972. Problem of student unrest: analysis of its causes and cure. In: Conflict of generations. National Publishing House, New Delhi: 181-198.

Buss, A.H. 1971. The psychology of aggression pays. In: Singer, J.L. (ed). The control of aggression and violence. Academic Press, New York: 75-105.

Dollard, J., Doob, L.W., Miller, N.E., Mowrer, O.H. \& Sears, R.R. 1939. Frustration and aggression. Yale University Press.

Haque, E. 2002. Political Behaviour: A psychological study of intergenerational differences, Ph.D. thesis, Department of Psychology, University of Rajshahi.

Heist, P. \& Somer, R.H. 1965. The mainsprings of the rebellion: a survey of Berkeley students. In: Lipset, S.M., Wolin, S.S. (eds): The Berkeley student revolt: facts and interpretation. Anchor Books, New York: 125-162.

Hussain, H. 1987. Aparadh biggan (Criminology), Muktadhara, Dhaka, $2^{\text {nd }}$ edn..

Kashem, M.A. 2008. Violent and aggressive attitudes of activists as related to personality and socio-demographic factors. Ph.D. thesis, Department of Psychology, University of Rajshahi.

Kempe, R.A. 1986. Development and collective violence-a theoretical perspective. Paper presented at the National Seminar on Collective Violence Genesis and Response. New Delhi.

Keniston. K. 1967. The sources of student dissent, The Journal of Social Issues, 23(3):108-135.

Miller, D. \& Challas, G. 1981. Abused children as adult presents: a twenty five year longitudinal study. Paper presented at the National Conference on Family Violence Research, Durham.

Paulus, G. 1967. A multivariate analysis study of student activist, student government leaders, and non-activists. In: Peterson, R.E. (ed): The student left in American higher education. Draft for Puerto Rico Conference on Student and Politics.

Peterson. R.E. 1966. The scope of organized student protest in 1964-1965. Educational Testing Service, Princeton.

Sinha, D. 1972. The Mughal syndrome: A psychological study of intergenerational differences. Tata McGraw-Hill, New Delhi. 